\title{
Praxeological Components of Biotech Companies' Corporate Control Systems Integrated Assessment
}

\author{
Kostyantyn Serdukov, Angelika Krutova, Oksana Nesterenko
}

\begin{abstract}
This study is aimed at development of the theoretical foundations corporate control systems modeling for biotech companies.Methods. The article uses the data about specialties of Ukrainian partnerships in biotech industry corporate control distribution. These data are processed by analytical alignment. Achievement of the objectives is carried out with help of general and special research methods, namely: dialectical approach, analysis and synthesis, systematization and generalization Results. It is proved that the biotechnology market is the most dynamically growing segment of the "new economy" that requires special attention from the mechanism of corporate control implementation and distribution. Research presents the mechanism of leveling corporate conflicts situations, distributed according with the levels of the partnership's architectural model. The appropriateness of expanding the corporate control mechanism motivational component by means of reflexive management tools has been developed. The scheme of integrating reflexive management tools into the component of information provision of the mechanism of corporate control is determined. Conclusions. The material presented in the article has a practical significance because, according to the results of the study proposed mechanism allows to direct reflexive influence on formation among stakeholders a proper vision of corporate control system architecture and content of its elements.
\end{abstract}

Keywords : corporate control, corporate relations, corporate rights packages, corporate security, partnership, strategic management

\section{INTRODUCTION}

In the last 40 years, the biotechnology sector, which has been described as the "New Industrial Revolution", has experienced phenomenal growth throughout the world. For this sector, the simplest of truisms has always held: what goes up must eventually come down. Markets peaked in 2015 and declined in 2016; payer pressure and US election year rhetoric weighed on the sector; drug approvals fell sharply; and biotech companies faced a dwindling supply of public market capital to fund R\&D in key US and European markets

Revised Manuscript Received on November 15, 2019

* Correspondence Author

Kostyantyn Serdukov ,Doctor of Economic Sciences, Professor,Kharkiv Institute of FinanceKyiv National University of Trade and Economics,5 Pletnevsky prov., Kharkiv 61003, Ukraine, e-mail: kfuduefin@gmail.com

Angelika Krutova,Doctor of Economic Sciences, Professor,Kharkiv State University of Food Technology and Trade, 333 Klochkivska Av., Kharkiv 61051, Ukraine, e-mail: ankrutova@ukr.net

Oksana Nesterenko ,Doctor of Economic Sciences, Professor,Kharkiv State University of Food Technology and Trade, 333 Klochkivska Av., Kharkiv 61051, Ukraine, e-mail: akseniya72@gmail.com
[1]. Today biotechnology is the most dynamically growing segment of the "new economy" - by about $10-12 \%$ per year. According to the Grand View Research company estimate, in the next 7 years, the global biotechnology market will grow by almost 2 times (from $\$ 400$ billion in 2018 to $\$ 727.1$ billion by 2025). Besides, companies in the biotech industries show higher returns. The net rate of return for biotech venture capital firms reaches $26.8 \%$ while venture capital funds of other industries show a yield of $21.8 \%$ [2]. Whilst the rewards from investing in biotechnological research may sound attractive, investment costs are often considerable. It has been estimated that in the United States, bringing a new drug to market may take some 10-12 years, at a cost of over \$US400 to $\$ 800$ million. [3]. Biotechnologies, which have now reached a qualitatively new level of controlled manipulation are becoming attractive to businesses and states all around the world and form large capitals. In the TOP-100, the main share of biotechnology companies $(75 \%)$ has capitalization in the amount of $\$ 4.5$ billion to $\$ 49$ billion. [4]. Thereby, businesses associated with innovative biotechnology developments and production can increase shareholders' profits tens and even hundreds times in a short period.

Desire of Ukraine to enter the global bio-industry with comparable volumes and efficiency of biotechnological production can be realized in the nearest future. Activities and efforts of transnational companies as well as national biotechnological clusters at the state and regional levels testify to this. Ukraine needs further steps for educational, technological and production capacities development in the field of biotechnology which requires integration with government and research and educational institutions involved in the creation of modern technologies and R\&D of the bio industry. Inter-regional and international cooperation opens great prospects for that.

At the same time, the dynamics of the activities of biotechnology organizations in the past years have shown a large fluctuation in terms of projects and financial outcomes [5]. All companies in the biotech industry, from start- ups to large international corporations, face new challenges due to changes in the organization of corporate management and control. They have to answer the question how they will achieve success amid unprecedented strategic and policy uncertainty [1]? Regulatory oversight and requirements for services and products quality are constantly increasing. Big data and intellectual technologies, that are available to stakeholders now, are forcing industry participants to fundamental revising of approaches to corporate control, paying particular attention to improving the transparency of activities. In today's 
environment, biotechnology industry participants need to be confident that their business-models, starting from the development stage of a new product and ending with its introduction to the market, is viable and will ensure further growth. This actualizes the need to substantiate the theoretical foundations of biotech companies' corporate control systems modeling, which is determined as the research objective.

\section{MATERIALS AND METHODS}

The integration of corporate control into the company's operations and decision-making can not only effectively improve the competitiveness of the company, but also protect the company's brand, discover new market opportunities, and achieve continuous profitability, thus ensuring the sustainability of the company [6]. Corporate relations and corporate organization in modern scientific research are considered, first of all, as forms of corporatism ideology implementation, according to which the joint activity of corporations (participants of corporate activities) should be deployed to achieve individual and collective goals and interests, the source of satisfaction of which is corporate cooperation within certain corporate organizations. However, the nature and patterns of development of this kind of cooperation, its organizational aspects and structural construction within the framework of existing business associations remains the subject of scientific discussions.

There is a fairly wide range of studies on assessing of investment attractiveness of joint-stock companies with public offering of shares, namely B. Smolin [7] (an approach to assessment of counteragents for technological cooperation is developed), T. Momot [8] (stages and approaches to shares attractiveness estimation is investigated), S. Ishchuk [9] (investment risks influence on local joint-stock companies' attractiveness is highlighted), O. Chernetska [10] (list of indicators of attractiveness is developed) and Yu. Lysenko [11] (approach to the definition of investments is outlined). At the same time, investment is not the only area that requires an assessment of business partnership attractiveness. As D. Yednovetsky [12] rightly asserts not only stocks issuers need to assess the investment attractiveness, but other types of business associations also as long as transformation of corporate control is based on the merger or venture investment.

It is necessary to note that when researchers operate on the investment attractiveness concept they, as a rule, interpret it as "investor's requirements satisfaction" [8, p. 57], "generalized assessment of the advantages and disadvantages of particular investments" [13, p. 393], "effect of investment in stock" [11, p. 29], etc. Taking into account the above-mentioned definitions of investment attractiveness of companies with public offering of shares and proposals of D. Yednovetsky let us to extend the approach to assessing of corporate rights packages attractiveness for evaluation of all business partnerships types attractiveness [12]. These proposals are seen to be particularly valuable with respect to the Law of Ukraine № 2210 [14] according to which joint-stock companies that have not expressly declared their publicity are considered to be private. In addition, if effective tools for evaluating of corporate rights packages value for public join-stock companies exist, for limited liability companies such instruments require a certain revision. At the same time, it should be noted that Article 24, paragraph 8, of the Law of Ukraine "On Limited Liability Companies" [15] (effective from 17.06.2018) states that "the cost of a participant's share is determined on the basis of aggregation of the market value of all partnership participants' shares in proportion to the size of the share of such participant". The empirical results show that corporate attractiveness displays a significant negative correlation with corporate control weaknesses [16, p. 408]. Accordingly, assessment of the corporate rights package attractiveness should be done with respect to the contribution of the corporate control implementation parameters given by ownership of corporate rights package. Besides it is necessary to draw attention to the limited practice of adjusting the evaluation results to the biotech companies of corporate control distribution parameters. For example, the assessment of integral property complexes value [17] in accordance with the Procedure for Determining the Value of Stakeholders [18] implies to the size of shares in the property ratio. At the same time, such approach can be applied only to shares offered for competitive sale as well as it does not envisage the presence or absence of an investor's desire to manage the company.

\section{RESULTS}

According to the objective of this study the emphasis should be placed not on the value of a corporate rights package, but on its attractiveness for investors. We are talking about limitations of fundamental analysis methods for determining the market or stock value of a partnership, which does not allow to take into account the type of investor (for example, lack of desire to participate in management, focusing only on extracting additional profits). Investment attractiveness of a joint-stock company depends on investors' goals and expectations regarding the prospects of partnership activities. Existing approaches investigate similar differences in the context of decision making by strategic and portfolio investors. An example of a description of such discrepancies is contained in the study [19, p. 207-215], where it is proposed to use different indicators of investment attractiveness assessment for each of the specified types of investors. At the same time, with respect to the above-mentioned Law [14] indicators of investment attractiveness assessing of limited liability company or a private limited company need more examinations because such indexes as "income per share", "cash flow per share" or "profitability rate" are no longer relevant.

\section{DISCUSSION}

Therefore, estimation of corporate rights packages attractiveness has to be based on hypothesis of the corporate control distribution parameters influence on such attractiveness. Moreover, it is proposed to foresee the impact of possible corporate control transformation on corporate rights packages attractiveness. Realization of this hypothesis involves formation of two directions of partnerships' parameters evaluation, correlation of which [Table-1] Since the assessment of attractiveness to a certain extent is a subjective process, it is proposed to formalize it using a fuzzy logical conclusion tools. The appropriateness of the use of fuzzy sets of tools is based on N. Pogostinskaya's statement [21] concerning inductivity (the impossibility of obtaining an integral value by calculating of 
composite indicators) and latent nature (lack of application of only one indicator for evaluation) of investment attractiveness. Besides we draw attention to the existence of indicates the proof of the hypothesis. The first of these areas determines the value of a business partnership, while the second one characterizes corporate control distribution and implementation parameters. This approach is used by $\mathrm{E}$. Maslyukova [20], who proposes, to correlate its investment quality with managerial capabilities when assessing the value of a share, but does not provide tools for such correlation.

According to developed approach to assessing the partnership's attractiveness the first group of indicators, which reflects company's effectiveness and parameters for assessing its market value. We consider the evaluation of a company or its corporate rights packages attractiveness as basic since only independent from corporate control functions indicators were selected. The corresponding composition of indicators $(\{X\})$ along with the logic of their inclusion in the partnership's attractiveness assessment is presented in Table 1 .

different approaches to description of selected indicators functions. For example, for the

Indicator of Return on Equity it is appropriate to apply the approach of A. Nedosekin and S. Frolov [22], which is based on the construction of histograms of trapezoidal membership functions. Anchor point is determined on the basis of the correlation between the mean $(\bar{x})$ and the mean square deviation ( $\sigma$ ). The median feature of belonging is described by following expression: $[\bar{x}-\sigma ; \bar{x}-0,5 \times \sigma$; $\bar{x}+0,5 \times \sigma ; \bar{x}+\sigma$ ]. Definition of this

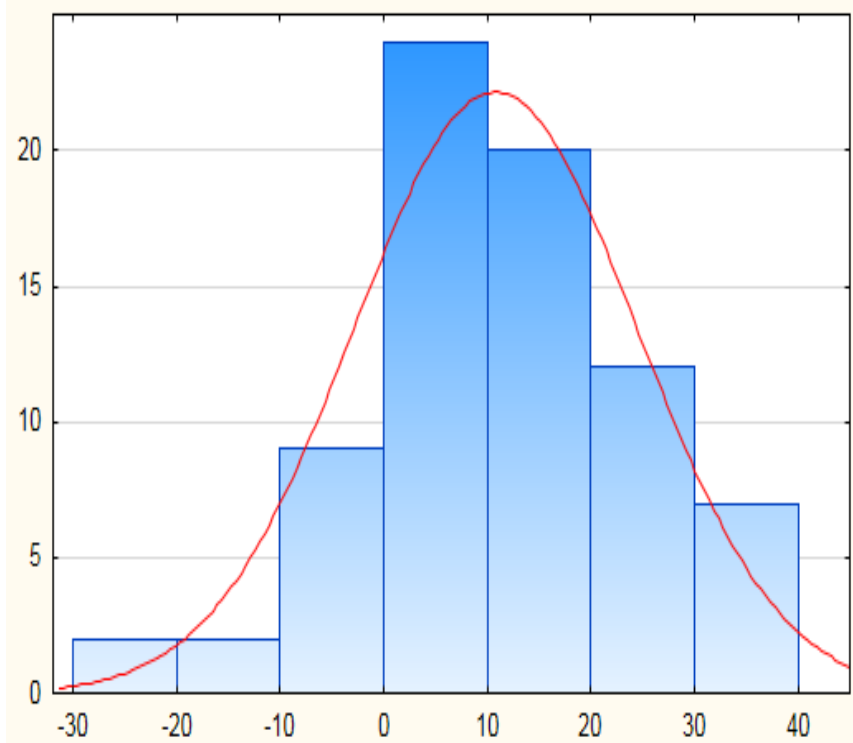

A) Histogram of the distribution of return on equity indicator values

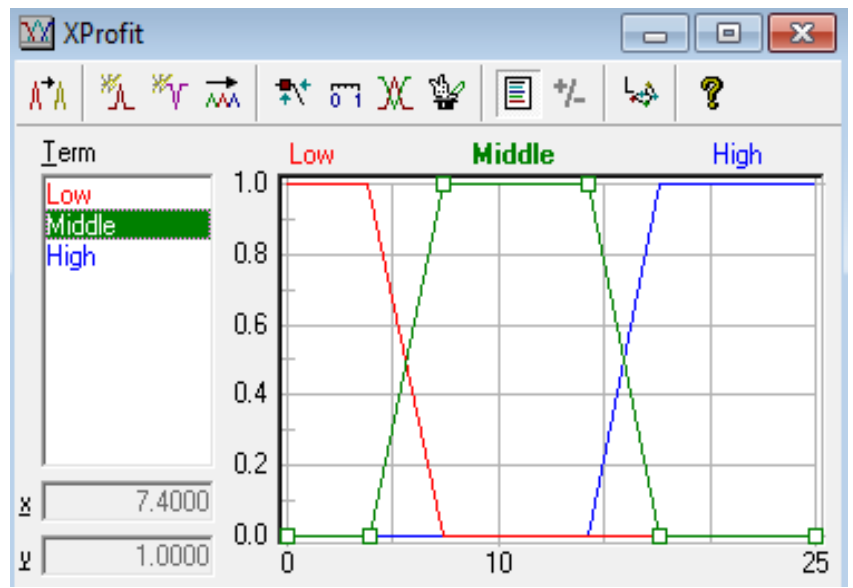

B) Presentation of ${ }_{t}$ equity capital profitability $\left(X_{\text {Profi }}\right)$ as linguistic variable in FuzzyTech software

For calculation of the $X_{\text {Profit }}$ level 78 companies, presented on the Agency for the development of the stock market infrastructure of Ukraine website, were used (evaluation of variable was based on the average value of $X_{P B K}$ at 10.8 and $\sigma$ $=6.8$ ). Functions of the remaining indicators accessories are shown in Fig. 2.

For the resource efficiency indicator $\left(X_{\text {Efficiency }}\right)$, the triangular function of affiliation with average value at average for all industries level was used (according to the State Statistics Committee of Ukraine in 2017, net income from the sale of all types of products amounted to 1.21 trillion UAH and its cost - 5,13 trillion UAH respectively, the average value of $X_{\text {Efficiency }}$ is equal to 1,21). In addition to presented in Table. 1 indicator, "perception of the partnership value by stakeholder's indicator" $\left(X_{\text {Value }}\right)$ is proposed in terms of belonging function \{insignificant, moderate, and important . It is suggested to calculate this indicator on the basis of the expenditure approach specified in [16] (in millions of hryvnias) and use it for the level of subject's interest in the partnership corporate rights package valuation determining. This indicator corresponds to shares spread and presented in Fig. 2.

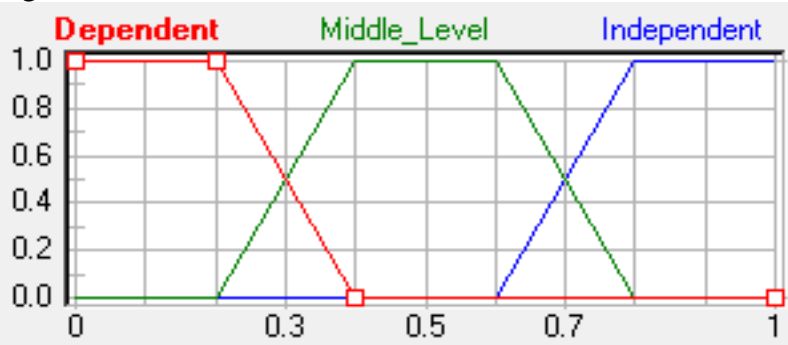

A) Financial independence level $\left(X_{\text {Finnnd })}\right.$

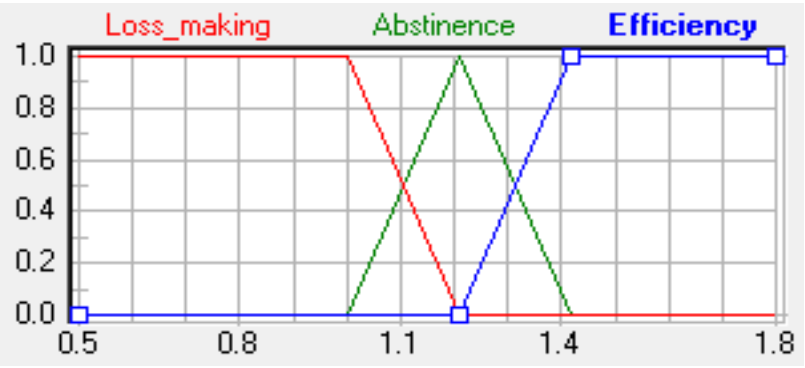

B) Resource efficiency $\left(X_{\text {Efficiency }}\right)$ 


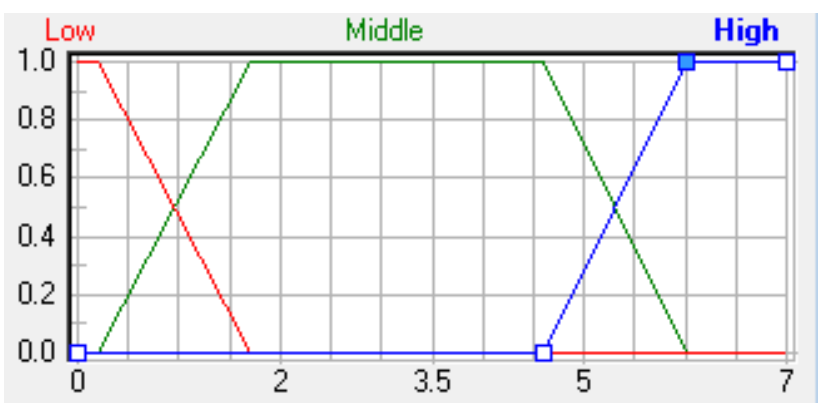

C) Non-current assets effectiveness $\left(X_{F o n d}\right)$

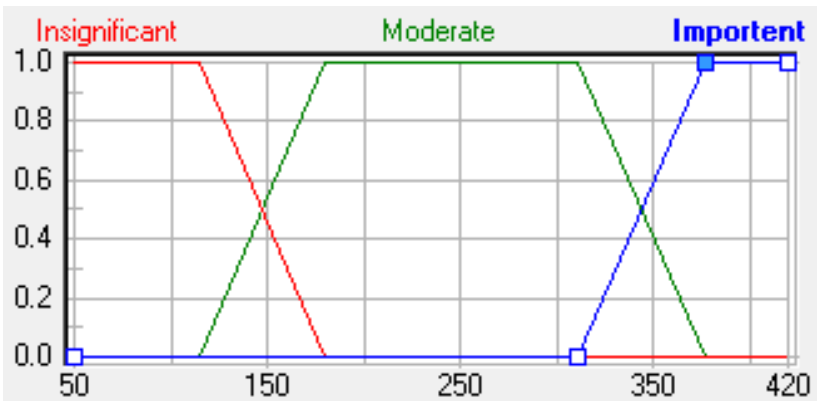

D) Partnership's value perceiving $\left(X_{\text {value }}\right)$

The second group of proposed attractiveness estimation indicators closely linked with the peculiarities of a partnership's corporate control system implementation. This group of indicators meets author's hypothesis about the influence of corporate control distribution parameters on the corporate rights package attractiveness. We propose to take into account the strategy of corporate control distribution while assessing the corporate rights package attractiveness. Consequently, we suggest to adjust the basic assessment of a partnership's corporate rights package attractiveness using indicators of corporate control distribution and implementation specified in the Table. 1. Besides we should note the necessity of evaluation of attractiveness from the point of subject of evaluation interests. For example, from the point of view of implementing the goal of hostile takeover by a competitor the falling performance of its activities may even increase the attractiveness. But since the consideration of such extreme cases seems inappropriate we propose to focus on the types of decisions that are made by the subject of evaluation. Such decisions may include identifying areas for improving the control distribution parameters in terms of increasing a partnership's attractiveness or considering the redistribution of corporate control functions. Indicators $(\{Y\})$ corresponding to these types of solutions are presented in the Table. 2.

The table 2 shows that the first set of indicators corresponds to the assessment of partnership's attractiveness current level, while second set of indicators is focused on the situation of reviewing of corporate control distribution parameters or estimating of partnership's corporate rights attractiveness. Then we will use proposed by A. Pylypenko and A. Litvinenko method [23, p. 143-151] concerning linguistic variables description adapted to the proposed sets of indicators for attractiveness assessing. Description of the accessories function for the indicators from the Table 1 and Table 2 is presented in the Table 3. Note the equality of two groups belonging functions represented in Table. 2, and differences of the interpretation of their impact on the partnership final attractiveness assessment. Hierarchical fuzzy conclusion procedure was considered as the basis for the level of partnership's corporate rights packages attractiveness assessment, determining of attractiveness is provided by displaying of the basic indicators on integral $(Y: X \rightarrow Z)$. The implementation of this mapping corresponds to the rule blocks for obtaining integral values: basic indicators $\left(Z_{\text {Base }}\right.$ calculation using the "Rule_for_base" block); characteristics of the corporate control distribution $\left(Z_{\text {Control }}\right.$ calculation using the "Rule_for_control" block); integral estimation of attractiveness ( $Z_{\text {Attraction }}$ calculation using the compliance of partnership's economic activities with its interests. Consequently, since a strategic investor seeks to influence decision-making, weight of the indicators characterizing the parameters of corporate control distribution, such as: $Y_{C O N S}$ and $Y_{P A R T}$, is set higher in determining the rules of fuzzy logical conclusion (Table 2). Venture investors are interested in partnership's cost. That is why the system of rules assumes the equivalence of the given in Table. 1 and Table 2 indicators influence. In this case the main thing is the desire for a balance between corporate control harmonization with company's interests and activities. Such system of rules can also be used for partnership's management evaluation, for example, for determining of the strategy transformations possibility. In order to interpret the results of assessing the level of partnership's "Rule_for_Attraction" block).

On the contrary strategic investor makes decisions based on information about attractiveness and control maturity transfer of the evaluation results to parametric values approach is used [24, p. 113-117]. Accordingly, an assessment of the results corporate control formation and implementation $(P c c)$ is determined as a function from corporate control maturity level (CCmaturity) and partnership's attractiveness (Patr) level. Therefore, parametric approach allowed us to determine the integral estimate using the matrices given in Fig. 3.

\section{CONCLUSION}

Formation and distribution of partnership's corporate control is influenced and as a result of a wide range of objective and subjective factors of external and internal environment. Implementation of proposed model of partnership's corporate control distribution, based on the use of the apparatus of the cooperative games theory, provides an opportunity to predict possible corporate conflicts and develop measures of partnership member's contradictions prevention. Developed in the research matrix of qualitative identification of the partnership's corporate control formation and implementation level allows simplification of the decision-making process regarding the corporate control parameters transformation. It determines the benchmarks for coordination of the main stakeholders' interests by means of a clearer understanding of the partnership position in the market and investment environment. 


\section{REFERENCES}

1. Beyond borders Biotechnology report 2017. [Electronic resource]. Available

https://www.ey.com/Publication/vwLUAssets/ey-https://www.ey.com /Publication/vwLUAssets/ey-beyond-borders-biotech-report-2017/\$FI LE/ey-beyond-borders-biotech-report-2017.pdf

2. Market Research Reports [Electronic resource]. Available at: https://www.grandviewresearch.com/services/market-research-reports

3. Biotechnology Intellectual Property Management Manual [Electronic resource].

$$
\text { Available }
$$

https://www.spruson.com/wp-content/uploads/2014/03/Biotechnolog y-IP-Management-Manual_Online.pdf

4. The largest companies in the world [Krupneyshye kompanyy myra 2015], Available

http://global-finances.ru/krupneyshie-kompanii-mira-2015.

5. Zbuchea A, Pînzaru F, Busu M, Stan S-O, Bârgăoanu A. Sustainable Knowledge Management and Its Impact on the Performances of Biotechnology Organizations. Sustainability. 2019; 11(2):359.

6. Dong Yang Hao et al. Corporate Social Responsibility, Internal Controls, and Stock Price Crash Risk: The Chinese Stock Market // Sustainability 2018, 10, 1675 p.

7. Smolin, B. A. (2010) Financial potential and assessment of the attractiveness of the enterprise [Finansovyiy potentsial i otsenka privlekatelnosti predpriyatiya], Moscow, Laboratory Books, $180 \mathrm{p}$.

8. Momot, T. V. (2006) Value-oriented corporate management from theory to practical implementation [Vartisno-oriyentovane korporatyvne upravlinnya vid teoriyi do praktychnoho vprovadzhennya], Kharkiv, KHNAMG, 380 p.

9. Ishchuk, S. O. (2011) Investment attractiveness of the western region of Ukraine: monograph [Investytsiyna pryvablyvist' Zakhidnoho rehionu Ukrayiny : monohrafiya], Lviv: Institute of Regional Studies, $212 \mathrm{p}$.

10. Chernetka, O. V. (2016) Model of information support of investment attractiveness of mechanical engineering enterprises [Model informatsiynoho zabezpechennya upravlinnya investytsiynoyu pryvablyvistyu pidpryyemstv mashynobuduvannya] // Problems of economics (Problemy ekonomiky). №. 4. Pp. 171-175.

11. Lysenko, Yu. G. (2005) Strategy of formation of investment attractiveness of metallurgical enterprises of Ukraine [Strategiya formirovaniya investitsionnoy privlekatelnosti metallurgicheskih predpriyatiy Ukrainyi], Donetsk, Southeast, Ltd., 381 p.

12. Ednovetsky, D. A. (2010) Analysis of the investment attractiveness of the organization [Analiz investitsionnoy privlekatelnosti organizatsii] Moscow, KNORUS, 376 p.

13. Bembe, A., Neubauer, F. (1997) Corporate governance: A face to face with paradoxes [Corporate governance: A face to face with paradoxes], Kyiv, Fundamentals, 302 p.

14. On Amendments to Certain Legislative Acts of Ukraine on Facilitation of Business and Investment Attraction by Securities Issuers: Law of Ukraine dated November 16, 2017 № 2210-VIII. [Pro vnesennya zmin do deyakykh zakonodavchykh aktiv Ukrayiny shchodo sproshchennya vedennya biznesu ta zaluchennya investytsiy emitentamy tsinnykh paperiv : Zakon Ukrayiny vid 16.11.2017 r. № 2210-VIII.]. Available at: https://zakon.rada.gov.ua/laws/show/2210-19.

15. About limited liability companies: Draft Law of Ukraine dated May 13, 2016 № 4666. [Pro tovarystva z obmezhenoyu ta dodatkovoyu vidpovidal'nistyu : Proekt Zakonu Ukrayiny vid 13.05.2016 №4666]. Available http://w1.c1.rada.gov.ua/pls/zweb2/webproc4_1?pf3511=59093.

16. W. Shu et al. Does corporate integrity improve the quality of internal control? / China Journal of Accounting Research 11 (2018) 407-427,

17. National standard number 3. "Estimation of integral property complexes": Resolution of the Cabinet of Ministers of Ukraine dated November 29, 2006 № 1655. [Natsional'nyy standart № 3. «Otsinka tsilisnykh maynovykh kompleksiv» : postanova Kabinetu Ministriv Ukrayiny vid 29.11.2006 r. № 1655.]. Available at: https://www.kmu.gov.ua/ua/npas/56644621.

18. On Approval of the Procedure for Determining the Estimated Value of Shares of Joint-Stock Companies offered for competitive sale: Order of the State Property Fund of Ukraine № 105 dated 23.01.2004. [Pro zatverdzhennya Poryadku vyznachennya otsinochnoyi vartosti paketiv aktsiy aktsionernykh

19. tovarystv, shcho proponuyut'sya dlya konkurentnoho prodazhu : Nakaz Fondu derzhavnoho mayna Ukrayiny vid 23.01.2004 № 105]. Available at: http://zakon3.rada.gov.ua/laws/show/z0135-04/page.

20. Popov, O. Ye., Kotov, A. M, Zaitseva, T. G. (2009) Distribution and realization of corporate control in the formation of capital of a joint-stock company: a monograph [Rozpodil i realizatsiya korporatyvnoho kontrolyu pry formuvanni kapitalu aktsionernoho tovarystva : monohrafiya], Kharkiv, Inzhek, 320 p.

21. Maslyukova, E.V. (2013) The investment attractiveness of the stock market for agro-food logistics companies [Investitsionnaya privlekatelnost ryinka aktsiy agroprodovolstvennyih logisticheskih kompaniy] // Economic sciences (Ekonomicheskie nauki). №. 7 (14) Pp. 34-35.

22. Pogostinskaya, N. N., Pogostinsky, R. L., Zhambekova, Yu. A. (2011) Economic diagnostics: theory and methods [Ekonomicheskaya diagnostika: teoriya i metodyi], Nalchik, Elbrus, 385 p.

23. Nedosekin, A.O., Frolov, S.N. (2008) Linguistic analysis of the histogram of economic factors [Lingvisticheskiy analiz gistogrammyi ekonomicheskih faktorov] // Vestnig VGU (Vestnig VGU). №. 2. S 48-55.

24. Pylypenko, A.A, Litvinenko, A.O. (2015) Organization of management of development of material and technical base of the enterprise: monograph [Organization of management of development of material and technical base of the enterprise: monograph], Kharkiv, FOP Zdorovyi Ya. A., $236 \mathrm{p}$

Lepeiko, T. I. (2015) Organization of marketing management of the enterprises of the machine-building cluster in the conditions of globalization: monograph [Orhanizatsiya marketynhovoho upravlinnya diyal'nistyu pidpryyemstv mashynobudivnoho klastera v umovakh hlobalizatsiyi: monohrafiya], Kharkiv, Gold Pages, 664 p.

\section{AUTHORS PROFILE}

Kostyantyn Serdukov ,Doctor of Economic Sciences, Professor,Kharkiv Institute of FinanceKyiv National University of Trade and Economics,5 Pletnevsky prov., Kharkiv 61003, Ukraine, e-mail: kfuduefin@gmail.com

Angelika Krutova,Doctor of Economic Sciences, Professor,Kharkiv State University of Food Technology and Trade, 333 Klochkivska Av., Kharkiv 61051, Ukraine, e-mail: ankrutova@ukr.net

Oksana Nesterenko ,Doctor of Economic Sciences, Professor,Kharkiv State University of Food Technology and Trade, 333 Klochkivska Av., Kharkiv 61051, Ukraine, e-mail: akseniya72@gmail.com 
Table-1

\begin{tabular}{|c|c|c|c|}
\hline Indicator & Features included in the model & Linguistic variable & Impact on the partnership attractiveness level hypothesis \\
\hline $\begin{array}{c}X_{\text {Profit }}-\text { equity capital } \\
\text { profitability }\end{array}$ & $\begin{array}{c}\text { Determined on the basis of trapezoidal function of } \\
\text { membership regarding to the average industry or } \\
\text { competitors profitability level }\end{array}$ & $\begin{array}{c}\text { Low } \\
\text { Middle } \\
\text { High) }\end{array}$ & $\begin{array}{c}\text { More attractive is the partnership that shows higher } \\
\text { than average for certain industry profitability so far } \\
\text { as it generates a higher rate of return on investments }\end{array}$ \\
\hline $\begin{array}{c}X_{\text {Finhnd }}-\text { financial } \\
\text { independence level }\end{array}$ & $\begin{array}{c}\text { Based on a trapezoidal function and financial } \\
\text { autonomy indicator }\end{array}$ & $\begin{array}{c}\text { Dependence } \\
\text { Average level } \\
\text { Autonomy }\end{array}$ & $\begin{array}{c}\text { Greater financial independence extends the list of } \\
\text { optimization options for the partnership's capital } \\
\text { structure and increases the number of strategic } \\
\text { alternatives. }\end{array}$ \\
\hline $\begin{array}{c}X_{\text {Efficiency }}-\text { resource } \\
\text { efficiency }\end{array}$ & $\begin{array}{c}\text { Constructed as a triangular membership function } \\
\text { with a prediction of the break-even point } \\
\text { comparison with the average for the selected } \\
\text { industry income hryvnia costs }\end{array}$ & $\begin{array}{c}\text { Unprofitability } \\
\text { Satisfactory } \\
\text { Efficiency }\end{array}$ & $\begin{array}{c}\text { Company with a high level of operational efficiency is } \\
\text { more attractive. In this case, any indicator of the } \\
\text { company's business activity can be used }\end{array}$ \\
\hline $\begin{array}{c}X_{\text {Fond }}-\text { non-current assets } \\
\text { effectiveness }\end{array}$ & $\begin{array}{c}\text { Constructed as a trapezoid function of return on } \\
\text { assets fixed assets profitability indicators with } \\
\text { orientation to the average industry value of the } \\
\text { indicator }\end{array}$ & $\begin{array}{c}\text { Low } \\
\text { Middle } \\
\text { High }\end{array}$ & $\begin{array}{c}\text { Company with a high level of return on assets, which } \\
\text { should adjust to the level of fixed assets depreciation } \\
\text { within the framework of the integral (taxonomic) } \\
\text { indicator }\end{array}$ \\
\hline
\end{tabular}

Table-2

\begin{tabular}{|c|c|c|c|}
\hline \multirow{2}{*}{$\begin{array}{l}\text { Symbol and content of the partnership } \\
\text { corporate governance evaluation }\end{array}$} & \multicolumn{2}{|c|}{ Content of the selected indicator } & \multirow{2}{*}{$\begin{array}{l}\text { Necessity of entering a certain } \\
\text { parameter for evaluation of the } \\
\text { partnership's attractiveness }\end{array}$} \\
\hline & $\begin{array}{l}\text { in terms of corporate rights current } \\
\text { distribution }\end{array}$ & $\begin{array}{l}\text { in terms of the certain corporate } \\
\text { rights package owner }\end{array}$ & \\
\hline $\begin{array}{c}Y_{H A R M}-\text { consistency of decisions } \\
\text { within the existing structure of } \\
\text { corporate rights distribution }\end{array}$ & $\begin{array}{l}\text { Score scale of corporate cooperation } \\
\text { rules and procedures assessment }\end{array}$ & $\begin{array}{c}\text { Score scale of possibility of } \\
\text { corporate conflicts overcoming } \\
\text { environment of formation }\end{array}$ & $\begin{array}{c}\text { Vision consolidation and } \\
\text { corporative-based conflicts } \\
\text { minimization }\end{array}$ \\
\hline $\begin{array}{c}Y_{C O N S}-\text { the ability to form a } \\
\text { consolidated vision of the partnership } \\
\text { development prospects }\end{array}$ & $\begin{array}{l}\text { corporate rights packages concentration } \\
\text { level in the framework of their owners } \\
\text { common strategic vision }\end{array}$ & $\begin{array}{l}\text { Volume of corporate rights } \\
\text { package, taking into account the } \\
\text { size of further property rights } \\
\text { consolidation }\end{array}$ & $\begin{array}{l}\text { Possibility of receiving a control packet or } \\
\text { owners efforts consolidation positively } \\
\text { affects the partnership's attractiveness }\end{array}$ \\
\hline $\begin{array}{l}Y_{V A R}-\text { dispersion (variability) of the } \\
\text { corporate rights package size level }\end{array}$ & $\begin{array}{l}\text { Calculated as a coefficient of variation of } \\
\text { contributions of partnership's members } \\
\text { in the authorized capital }\end{array}$ & $\begin{array}{c}\text { Perspective variability after the } \\
\text { corporate control transformation } \\
\text { process }\end{array}$ & $\begin{array}{c}\text { Dispersion and variability ratio for different } \\
\text { types of stakeholders have different impact } \\
\text { on the partnership's attractiveness } \\
\text { assessment }\end{array}$ \\
\hline $\begin{array}{l}Y_{\text {PART }}\left(Y_{\mathrm{Y} Y}\right)-\text { proportion of participants } \\
\text { forming a coalition (control) package }\end{array}$ & $\begin{array}{c}\text { The share of participants who form a } \\
\text { coalition in the total number of } \\
\text { participants }\end{array}$ & $\begin{array}{l}\text { Possibility of joining a coalition for } \\
\text { participants with a certain share }\end{array}$ & $\begin{array}{c}\text { Increasing the number of participants } \\
\text { increases the risk of control redistribution } \\
\text { and has a reverse effect on partnership's } \\
\text { attractiveness }\end{array}$ \\
\hline
\end{tabular}

Table 3

\begin{tabular}{|c|c|c|c|c|c|c|}
\hline Variable symbol & \multicolumn{6}{|c|}{ Function description } \\
\hline \multirow[t]{2}{*}{ FuzzyTech environment } & \multicolumn{2}{|r|}{ Low } & \multicolumn{3}{|c|}{ Middle } & High \\
\hline & equals 1 & decreases from 1 to 0 & increases from 0 to 1 & equals 1 & decreases from 1 to 0 & increases from 0 to 1 \\
\hline \multicolumn{7}{|c|}{ Indicators for estimating the base part of attractiveness } \\
\hline$X_{\text {Profit }}$ & $0-3,9$ & $3,9-7,4$ & $3,9-7,4$ & $7,4-14,2$ & $14,2-17,6$ & $14,2-17,6$ \\
\hline$X_{\text {FinInd }}$ & $0-0,2$ & $0,2-0,4$ & $0,2-0,4$ & $0,4-0,6$ & $0,6-0,8$ & $0,6-0,8$ \\
\hline$X_{\text {Efficienc }}$ & $0-1$ & $1-1,21$ & $1-1,21$ & 1,21 & $1,21-1,42$ & $1,42-1,63$ \\
\hline$X_{\text {Fond }}$ & $0-0,2$ & $0,2-1,7$ & $0,2-1,7$ & $1,7-4,6$ & $4,6-6,0$ & $4,6-6,0$ \\
\hline \multicolumn{7}{|c|}{ Elements of setting the system of fuzzy logical conclusion } \\
\hline$X_{\text {Value }}$ & $0-115$ & $115-180$ & $115-180$ & $180-311$ & $311-377$ & $311-377$ \\
\hline \multicolumn{7}{|c|}{ Assessing the level of corporate control mechanism formation or determining the influence parameters of transformation of corporate control distribution } \\
\hline$Y_{H A R M}$ & $0-2$ & $2-4$ & $2-4$ & $4-6$ & $6-8$ & $6-8$ \\
\hline$Y_{V A R}$ & $0-5$ & $5-10$ & $5-10$ & $10-20$ & $20-15$ & $20-15$ \\
\hline$Y_{P A R T}$ & $0-25$ & $25-50$ & $25-50$ & 50 & $50-75$ & $50-75$ \\
\hline
\end{tabular}

Fig. 3

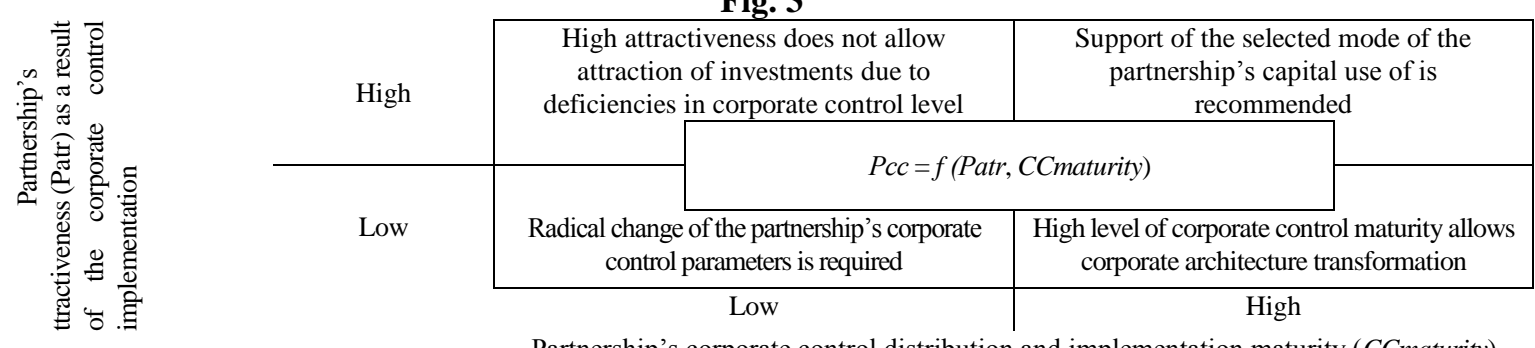

Partnership's corporate control distribution and implementation maturity (CCmaturity) 